\title{
PERBANDINGAN PENGGUNAAN FIKSASI HAIR SPRAY DENGAN FIKSASI RUTIN PADA PAP SMEAR DENGAN METODE BETHESDA
}

\author{
Dian Yuliartha Lestari \\ Fakultas Kedokteran, Universitas Muhammadiyah Malang, J1. Bendungan Sutami 188 A Sumbersari malang, \\ Lowokwaru, Kota Malang, 65145, Indonesia, (0341) 582060
}

\begin{abstract}
ABSTRAK
Latar belakang. PAP smear merupakan metode deteksi dini yang rutin digunakan untuk lesi peradangan serta kanker serviks di seluruh dunia. Metode fiksasi basah untuk PAP smear saat ini selain menggunakan alkohol, juga menggunakan Hair spray. Tujuan. Untuk membandingkan kualitas fiksasi menggunakan alkohol dan hair spray. Metode. Merupakan penelitian observasional analitik, dengan total sampling dari bulan September-Desember 2014. Variabel yang dinilai adalah adekuat spesimen, kualitas staining, ada tidaknya artefak, serta ada tidaknya sel yang degenerasi. Uji statistik menggunakan Uji Kesesuaian Kappa, dikatakan sesuai jika koefisien kappa $>0,6(\mathrm{p}<0,05)$. Hasil. Didapatkan jumlah sampel sebanyak 122 sampel. Hasil koefisien kappa untuk adekuat spesimen sebesar 0,792. Hasil koefisien kappa untuk kualitas staining sebesar 0,627. Hasil koefisien kappa untuk ada tidaknya artefak sebesar 0,196. Hasil koefisien kappa untuk ada tidaknya sel yang degenerasi sebesar 1,000. Kesimpulan. Terdapat kesesuaian antara penggunaan fiksasi menggunakan alkohol maupun hairspray, dalam hal adekuat sel, kualitas staining, maupun ada tidaknya sel yang degenerasi.
\end{abstract}

Keyword : PAP smear, alkohol, hairspray

\section{PENDAHULUAN}

PAP smear merupakan metode deteksi dini yang rutin digunakan untuk lesi peradangan serta kanker serviks di seluruh dunia. Ditemukan oleh George P. Papaniculaou pada tahun 1941, saat ini PAP smear terbukti dapat menurunkan angka kematian kanker serviks sebesar 70-80\%. PAP smear mampu mendeteksi lesi pra kanker sehingga dapat dilakukan penatalaksanaan yang cepat. Prinsip pemeriksaan PAP smear adalah dengan teknik pulasan dari sampel yang diperoleh dari epitel serviks. Sampel-sampel ini dapat diambil oleh bidan, dokter umum, maupun dokter spesialis kebidanan dan kandungan.

Untuk mendapatkan hasil yang tepat, maka diperlukan prosedur yang tepat pula. Teknik pengambilan PAP smear harus tepat secara lokasi, cara, serta fiksasi yang digunakan. Lokasi pengambilan PAP smear untuk menghasilkan hasil yang adekuat menurut Bethesda (2001) adalah di skuamokolumnar junction dari porsio serviks. Cara pengambilan PAP smear juga harus tepat, yaitu menggunakan spatula ayre atau cytobrush dengan diputar sebesar $360^{\circ}$. Fiksasi juga memegang peranan penting untuk menghasilkan hasil yang adekuat. Tanpa fiksasi yang tepat, sel akan lisis dan tidak akan bisa terbaca.

Terdapat dua macam fiksasi yang biasa digunakan pada PAP smear konvensional, yaitu fiksasi basah dan fiksasi kering. Fiksasi basah menggunakan larutan alkohol 95\% sementara pada fiksasi kering, obyek glass dibiarkan kering oleh udara atau menggunakan bantuan air-dryer.

Fiksasi basah dapat dilakukan dengan dua metode, yaitu obyek glass hasil smear dicelupkan ke dalam wadah berisi alkohol 95\% selama 30 menit, atau menggunakan semprot khusus (cytovix) yang berisi larutan alkohol 95\% dengan cara disemprotkan berjarak $10-15 \mathrm{~cm}$ dari obyek glass. Cytovix lebih cepat dibandingkan alkohol celup dalam segi waktu serta tidak membutuhkan wadah khusus, akan tetapi lebih mahal dalam segi harga. Berdasarkan hal tersebut, klinisi lebih suka menggunakan fiksasi basah dengan metode semprot, akan tetapi tidak menggunakan cytovix, melainkan hair spray.

Hair spray adalah salah satu kosmetika yang sering digunakan pada rambut yang salah satu kandungannya adalah etanol 95\%. Berdasarkan American Society of Cytopatoholgy, Hair Spray atau penyemprot rambut, seharusnya tidak boleh digunakan untuk fiksasi basah, dikarenakan didalam komposisi hair spray didapatkan kandungan kimia selain etanol $95 \%$, yang bisa ikut tersemprot ke obyek glass dan dapat berpengaruh terhadap kualitas hasil.

Oleh karena itu, peneliti ingin meneliti tentang perbedaan fiksasi PAP smear antara hair spray dengan alkohol celup baik dari segi kualitas sel yang dilihat dari ada tidaknya artefak, ada tidaknya sel yang degenerasi atau lisis, serta adekuat atau tidak.

\section{METODE PENELITIAN}

Penelitian ini menggunakan studi observational analitik dengan menggunakan metode cross sectional. Populasi dan sampel yang diambil pada penelitian ini adalah semua slide PAP smear pasien di RS UMM pada September - Desember 2014, jumlah total sebanyak 122 sampel. Slide yang diperoleh dari pasien, dimana tiap pasien yang melakukan PAP smear diambil smear sebanyak 2 obyek glass. Satu obyek glass menggunakan fiksasi basah, obyek glass lainnya menggunakan fiksasi hair spray.

Variabel yang dinilai adalah adekuat atau tidak, ada tidaknya artefak, kualitas pengecatan baik atau cukup, serta ada tidaknya sel yang degenerasi. Untuk mengetahui adekuat tidaknya hasil PAP smear menggunakan kriteria Bethesda yaitu dinilai adalah tingkat selularitas (ringan/sedang/berat), kelenjar endometrium (+/-). Untuk mengetahui ada tidaknya 
artefak dilihat tingkat sel radang (ringan/sedang/berat), serta eritrosit (ringan/sedang/berat). Sel yang degenerasi dibagi menjadi 2 kelompok (+/-). Penilai seorang patolog independen, dengan tidak mengetahui tentang sampel penelitian (blind trial). Uji statistik menggunakan kesesuaian Kappa untuk membandingkan antara fiksasi alkohol dan hairspray.

\section{HASIL DAN PEMBAHASAN}

Sampel yang diperoleh dari bulan September 2014 hingga Desember 2014 berjumlah 122 pasien, dengan rentang usia 28-82 tahun. Dari hasil pemeriksaan pap smear, diagnosis ditegakkan berdasarkan 3 kriteria, yaitu: NILM (Negative for Intraepithelial Lesion or Malignancy) dengan keradangan sebanyak $78 \%$, NILM dengan infeksi jamur sebanyak $12 \%$, serta NILM dengan normal smear sebanyak $32 \%$.

\section{Tabel 1. Data distribusi variabel penelitian}

\begin{tabular}{|c|c|c|c|}
\hline \multirow[t]{2}{*}{ Keterangan } & \multicolumn{2}{|c|}{ Jenis Fiksasi } & \multirow{2}{*}{ Koefisien Kappa } \\
\hline & Alkohol & Hair spray & \\
\hline adekuat & & & 0,792 \\
\hline - Iya & 118 & 116 & \\
\hline - tidak & 4 & 6 & \\
\hline staining & & & 0,627 \\
\hline - cukup & 24 & 40 & \\
\hline - baik & 98 & 82 & \\
\hline Artefak & & & 0,196 \\
\hline - ada & 4 & 29 & \\
\hline - tidak ada & 118 & 93 & \\
\hline Degenerasi & & & 1,000 \\
\hline - ada & 1 & 1 & \\
\hline - tidak ada & 121 & 121 & \\
\hline
\end{tabular}

Dari tabel 1 dapat dilihat bahwa koefisien kappa untuk variabel penelitian adekuat atau tidak, kualitas staining, maupun degenerasi sebesar $>0,6$, yang artinya tidak terdapat perbedaan antara perlakuan fiksasi menggunakan alkohol maupun menggunakan hair spray. Akan tetapi untuk variabel penelitian ada tidaknya artefak, didapatkan koefisien kappa sebesar <0,6 yang artinya terdapat perbedaan antara perlakuan fiksasi menggunakan alkohol maupun hair spray.

Penggunaan hair spray sebagai bahan fiksasi untuk prosedur sitodiagnostik sudah pernah dilaporkan pada tahun 1969. Pada saat itu hair spray dinyatakan memiliki efektifitas yang sama dengan fiksatif yang menggunakan aerosol.

Pada penelitian yang dilakukan oleh Idoko et al (2014), memberikan hasil bahwa penggunaan hair spray untuk fiksasi dapat mempertahankan struktur sel, baik inti maupun sitoplasma sel. Selain itu, pada penelitian Idoko et al, juga dikemukakan bahwa penggunaan fiksasi dengan hair spray dapat meminimalisir kontaminasi dari preparat yang lain, akibat pencelupan yang berulang kali pada tabung alkohol.

Pada penelitian ini, didapatkan koefisien kappa untuk variabel adekuat atau tidaknya sampel sebesar 0,792, yang artinya hasil perlakukan fiksasi menggunakan alkohol serupa dengan hasil perlakukan fiksasi menggunakan hair spray. Bahan pap smear dikatakan adekuat jika didapatkan kelompok sel skuamous yang cukup seluler serta didapatkan adanya kelompok endocervix. Merujuk pada hasil penelitian
Idoko et al, bahwa struktur sel masih dapat dilihat dengan menggunakan fiksasi hair spray, maka tidak terdapat masalah yang serius dalam identifikasi jenis sel. Akan tetapi jika dilihat dari tabel 1, masih didapatkan sampel yang tidak adekuat, hal ini dapat disebabkan karena teknik pengambilan yang kurang tepat.

Untuk kualitas staining, dikategorikan menjadi cukup dan dikatakan baik jika kualitas staining dapat membedakan sel skuamous yang superficial, intermediate, maupun sel basal, tanpa melihat struktur sel. Karena sel skuamous yang superficial, jika menggunakan pengecatan papaniculaou akan menghasilkan sitoplasma yang keoranyean. Mendekati sel basal, warna yang dihasilkan sitoplasma menjadi biru. Pada penelitian ini didapatkan hasil koefisien kappa sebesar 0,627, yang artinya tidak terdapat perbedaan perlakuan baik antara fiksasi menggunakan alkohol maupun fiksasi menggunakan hair spray.

Hasil yang berbeda dapat dilihat pada variabel penelitian ada tidaknya artefak. Pada variabel tersebut didapatkan koefisien kappa sebesar 0,196, yang artinya terdapat perbedaan perlakuan antara fiksasi menggunakan alkohol maupun menggunakan hair spray. Hal ini dapat dikarenakan karena kandungan hair spray bermacam-macam, sehingga pada saat disemprotkan maka akan tertinggal di obyek glass. Pada umumnya hair spray selain mengandung ethanol, juga mengandung butane, isobutene, aqua, vinyl codecanoatecopolymer, aminomethylpropanolol, PEG-12, dimetichone, parfum, dan benzophenone-3. Partikel-partikel inilah yang dapat melekat pada obyek glass saat hair spray disemprotkan. Dimana partikel tersebut tidak didapatkan dari penggunaan fiksasi yang murni alkohol.

Untuk variabel penelitian yang ada tidaknya sel yang degenerasi, didapatkan koefisien kappa sebesar 1,000. Hal ini bermakna tidak terdapat perbedaan fiksasi antara alkohol dengan hair spray. Pada tabel 1 dapat dilihat baik fiksasi menggunakan alkohol maupun hairspray terdapat 1 sampel yang sel nya degenerasi. Hal ini dapat disebabkan oleh karena keterlambatan fiksasi. Sel dapat degenerasi jika terlambat dilakukan fiksasi, sehingga penggunaan hair spray maupun alkohol jika dilakukan secara cepat dapat mencegah sel untuk degenerasi.

\section{KESIMPULAN}

Terdapat kesesuaian antara penggunaan fiksasi menggunakan alkohol maupun hairspray, dalam hal adekuat sel, kualitas staining, maupun ada tidaknya sel yang degenerasi.

\section{DAFTAR PUSTAKA}

American Cancer Society, 2014, Cervical Cancer Prevention and early Detection, Atlanta: ACS, pp. 1-25.

Dinas Kesehatan Provinsi Jawa Timur, 2013, Profil Kesehatan Provinsi Jawa Timur tahun 2012, Surabaya: Dinkes Provinsi Jawa Timur. 
Holm, K. Grinsted, P. Poulsen, EF. Fenger, C. 1988. Can Hairspray be used as a smear fixative? A comparison between two types of coating fixative. Acta cytol.1998.May-Jun:31(3):422-4. www. ncbi. nlm. nih.gov/pubmed/3376710. Diakses 27 juni 2016.

Idoko, J. Enemari, JO. Okolo, SC. Yaro, DJ. Akpulu, P. Mairiga, AA et al. 2014. Hairspray (NOVA) as a Substitute for Routin Fixatives in Cervical Smear. J Pharm Biomed Sci 2014; 04(04): 327-331. https:// www.academia.edu. Diakses 27 Juni 2016. 